\title{
Inheritance and Comparison of Phenotypic Characters from Hybrid Chicken GK-Bro (Gallus gallus Linnaeus, 1758)
}

\author{
PUTU AYU DAMAYANTI ${ }^{1}$, BUDI SETIADI DARYONO ${ }^{1 *}$, I WAYAN SWARAUTAMA \\ MAHARDHIKA ${ }^{1}$ \\ ${ }^{1}$ Laboratory of Genetics and Breeding, Faculty of Biology, Universitas Gadjah Mada \\ Jl. Teknika Selatan, Sekip Utara, Sleman, Yogyakarta, Indonesia. 55281 \\ *Email: bs_daryono@mail.ugm.ac.id
}

Received 08 July 2019; Received in revised form 05 October 2019;

Accepted 05 December 2019; Available online 30 December 2019

\begin{abstract}
GK-Bro (Gallus gallus Linnaeus, 1758) is a hybrid chicken from crossing between $\circ$ F2 Broiler ${ }^{\lambda}$ F2 Golden Kamper that have variation of phenotypic character. To meet the market's demand, GK-Bro must have prime phenotypic character in both quantity and quality. This research aims to examine the phenotype character that occur in GK-Bro by the character of feet morphometry, crest's shape, feather's color, and feet' color. The parental chicken is crossed in Innovation and Agriculture Centre of Universitas Gadjah Mada (Indonesia) and produce 11 chickens with five males and six females filial. The filial are maintained intensively and qualitative data were observed at the end of seven weeks, classified based on the percentage of the phenotypic class. Quantitative characters that observed were tibia and femur length after seven weeks, using control pelung, broiler and F1 broiler. Quantitative data showed that the average length of the tibia and femur of GK-Bro is lower when compared to the control but the ratio of feet morphometry is closer to pelung. Qualitative data classified crest form in one class, feather's color in 4 classes and feet' color in 3 class.
\end{abstract}

Keywords: characterization; chicken; morphometric; Indonesia

\section{INTRODUCTION}

Indonesia is a developed country and one of the national food resources come from chicken farming. Indonesia has local chicken species with unique phenotypic characteristics that are distributed in various regions as result from domestication of red jungle chickens, chickens from China and Europe (Ulfah et al., 2015; Nataamijaya, 2005; Maw et al., 2012; Setianto et al., 2017). There are 31 local chicken strains with distinctive appearance characteristics (Hidayat \& Asmarasari, 2015; Nataamijaya, 2000), and increased to 34 in 2016 (Henuk \& Bakti, 2016). To maximize livestock production, genetic breeding methods are used by crossing different breeds. The proportion of the body is one of the selling values of chicken livestock. Chicken that has a sturdy posture will be preferred from chicken with weak and unstable postures. The feet morphometry were consist of tibia and femur length. The length of femur and tibia will affect the selling value in the commercial industry
(Mir et al., 2017; Applegate \& Lilburn, 2002; Salaam et al., 2016).

The size of the femur and tibia are parameters determined by genetics and the environment. Qualitative characters were characters that can be seen by the eye, not have quantitative values, and can be classified into categories. Some qualitative characters that can be observed were crest's form, feather's color and feet' color (shank). Broiler is a popular strain hence of their fast growth rate and can be harvested at the age of 5 weeks (Dharmawan $e t$ al., 2015).

Broiler has short postures, white feathers, and weights that cause these chickens to not move quickly. To improve the proportions, Broiler was cross with pelung chicken. Pelung chicken is a native chicken that has a high and sturdy posture and has great potential for broilers because roosters weigh $\pm 3.5 \mathrm{~kg}$ and hens reach $\pm 2.5 \mathrm{~kg}$ at the age of 52 weeks (Hidayat et al., 2016). Since 2006 the Laboratory of Genetic and Breeding, Faculty of Biology has developed a breeding program to 
get chickens with postures such as pelung chickens and have high productivity such as broiler chickens. In the study, it has succeeded in developing an F1 Broiler which weighs 1100-1500 grams at the age of seven weeks (Mahardhika \& Daryono, 2019). Kampung Super (Kamper) is a hybrid from cross between male Pelung chickens and female Layer chicken (Puspita et al., 2017). In 2013-2014, F1 Kamper successfully developed with weights reaching 911-1100 grams at the age of seven weeks (Lesmana, 2016). F1 Kamper has high productivity of egg and meat, but the results of these crosses are still heterozygous with filial's feather range from plain white, brown-white, brown-blackly, black-blazing, to plain black color. The highest productivity filial is golden brown feather. This selective breeding chicken is called Golden Kamper (GK) which is made by broods for subsequent crosses (Habibah, 2018). This paper will study the quantitative and qualitative characters inherited by filial.

\section{MATERIALS AND METHODS}

This research was conducted at Agriculture Centre of Universitas Gadjah Mada, Kalitirto, Yogyakarta. The parental used were $q$ F2 Broiler of F2 Golden Kamper. Materials used are semi-analytic scales KrisChef EK9350H, DOC (Day Old Chicken) bamboo cage, 15-watt bulb, place for feed and water, camera CANON EOS 200D, Medline, egg tray, egg incubator, tissue, parental cage K.13 Gama Ayam and egg stimulant MEDION, Vitamin VITACHICK and dietary feed BR I for chick up to seven weeks and AD II feed for chickens over seven weeks old.

Parental Preparation. Parental chicken that has high reproductivity was chosen and the cages for breeding were prepared. The parental must be healthy and active in producing eggs and have to familiarize each other. The parental maintained by giving food and water every day and mix egg stimulants in the water two times a week. The parental consist of one male and one female parental.

Egg Collection and Incubation. If the parental start producing an egg, the egg must be collected and incubated for twenty-one days until hatching. The average egg produced is 34 eggs per day.

Maintenance. DOC in the first week is friable so it has to be placed in a warm cage with five-watt yellow lamp and enough water and food. Once a week the DOC is supplied vitamin to optimize the growth. DOC that survived through this study consist of eleven chicken.

Phenotype Observation and Measurement. The measurement of femur and tibia was done every week and observation of qualitative trait-like crest form, feather color and feet color are done in the end of seven weeks and data were analyzed by Microsoft Excel 2013.

\section{RESULT AND DISCUSSION}

Qualitative phenotype characters of filial chicken were observed after seven weeks or 49 days. This observation was done because seven weeks is a representative age for observing characteristics, both qualitative and quantitative before chickens enter the reproductive period. Qualitative characters are traits that cannot be measured but can be classified into different phenotypic categories. The qualitative characters observed included the shape of the crest, feet color and feather (Table 1). In contrast to quantitative polygenic characters, qualitative characters are under the control of one or more genes, with little modification of environmental factors that can obscure the effects of genes (Ben-Zaken et al., 2019; Lobo, 2008; Cahill \& Provance, 2002).

Table 1. Qualitative character of GK-Bro

\begin{tabular}{ccc}
\hline Character & Classification & Percentage (\%) \\
\hline Crest shape & Single & 100 \\
\hline Feet's color & White & 54.55 \\
& Yellow & 36.36 \\
\cline { 2 - 3 } & Black & 9.09 \\
\hline Feather's color & Black-brown & 9.09 \\
\hline & White-black & 27.3 \\
\hline
\end{tabular}




\begin{tabular}{lcc}
\hline & Brown-white & 36.4 \\
\cline { 2 - 3 } & White & 27.3 \\
\hline
\end{tabular}

Qualitative character is one of the characters that show chicken productivity besides its morphometry. This character is inherited from genetic recombination of male parent and female parent. From 11 chickens, all had a single crest shape, and six chickens had white feet, four chickens had yellow feet color and one chicken had a blackish green color. The purpose of crossing chickens is to get filial that is close to the character of native chickens so that the color of the chicken feet that aimed is yellow. White feet can still be accepted on the market while the blackish-green color is not preferred in Indonesia. Black and green feet are preferred in Thailand. The color of feathers in
11 chickens was divided into four phenotypic classes which can be observed, namely the brown-black color consisting of one chicken, white-black color consisting of three chickens, white-brown color consisting of four chickens, and white consisting of three chickens. Whitebrown is white which has a brown spread on the chest, neck and wings. White-black is white with a variety of black colors, while the brownblack color is a golden brown color combination with black variations, which can be inherited from black pelung and golden kamper. The inheritance of feather color can be observed in Figure 1.

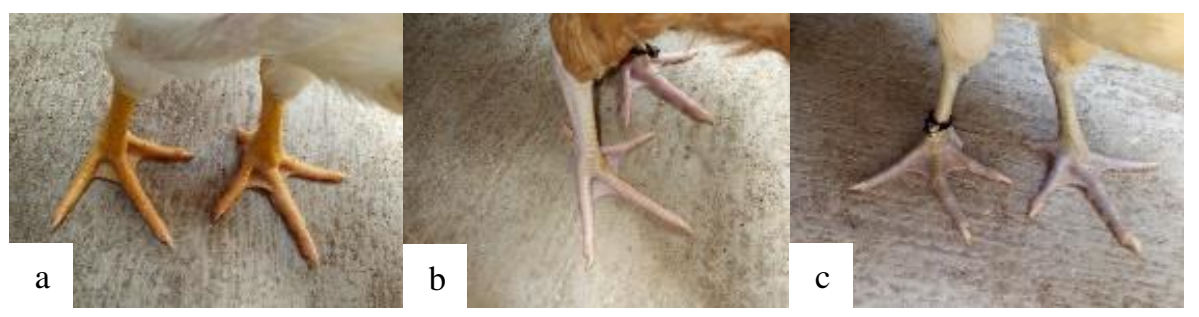

Figure 1. Feet color classification: a. Yellow; b. White; c. Black

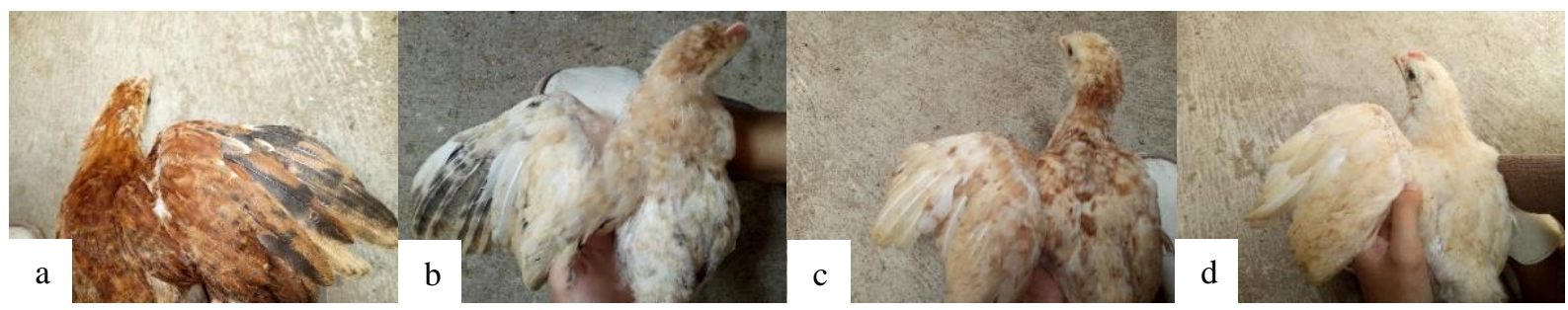

Figure 2. Feather's color classification: a. Black-brown; b. White-black; c. White-brown; d. White

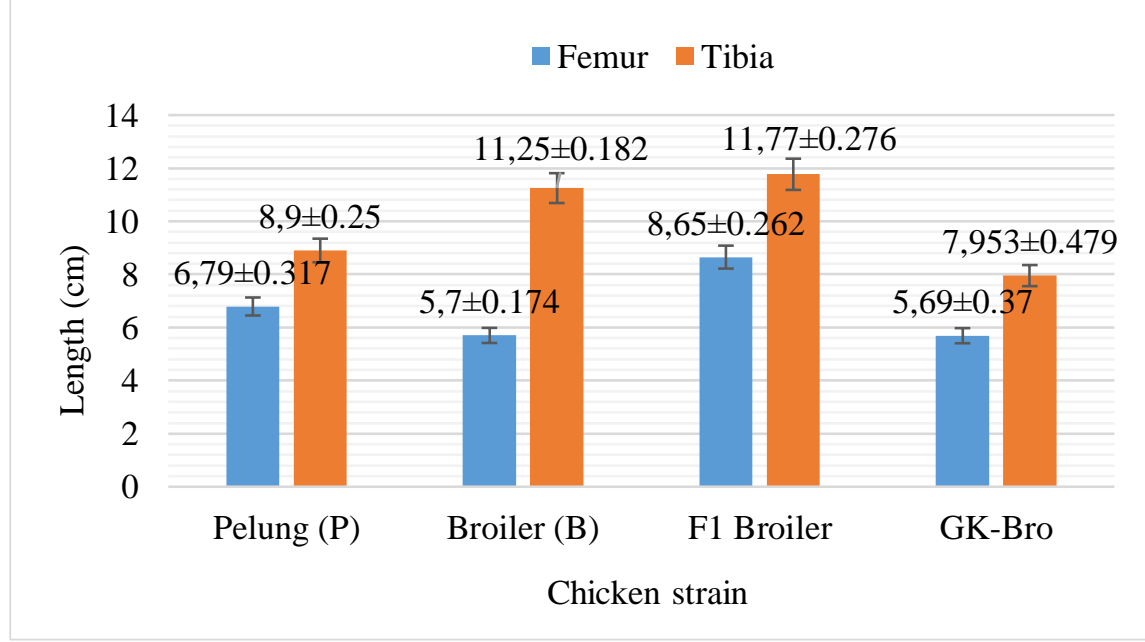

Figure 3. Comparison of tibia and femur length between GK-Bro with control 
Inheritance of feather color is a character influenced by an on-off mechanism on gene expression (Chang et al., 2010; Li et al., 2012; Minvielle et al., 2002; McGraw et al., 2005). Genes carrying the properties of white feathers in broilers have become heterozygous with repeated marriages thus the offspring of the crossing of Golden Kamper no longer have dominant white feathers, but feathers with brown color variations as in their parents Golden Camphor. In addition, the black color derived from pelung is still evident in some filials. Feather expression is an expression controlled by polygenes and the environment (Moiseyevaa et al., 2003; Wiebe \& Bortolotti, 2001).

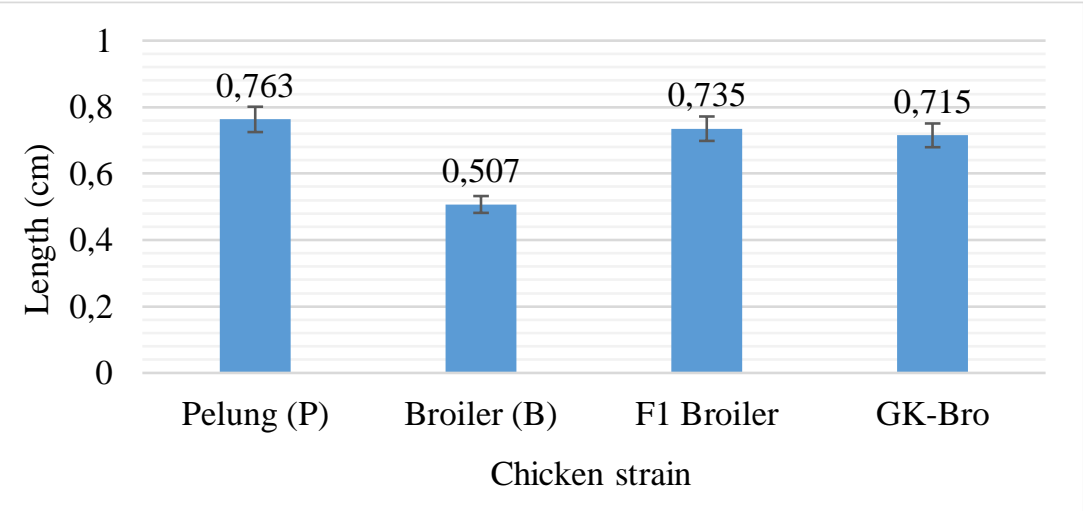

Figure 4. Ratio comparison of tibia and femur length between GK-Bro with control

Control data is the length of the femur and tibia of pelung chicken, broiler chicken, and $F_{1}$ broiler chicken (Figure 3). When compared, it can be seen that the femur and tibia ratio in GKBro is closer to the femur and tibia ratio in Pelung and F1 broiler control (Figure 4). Pelung control has femur length $(6.79 \pm 0.317 \mathrm{~mm})$ and tibia $(8.9 \pm 0.25 \mathrm{~mm})$, broiler control has femur length $(5.7 \pm 0.174 \mathrm{~mm})$ and tibia $(11.25 \pm$ $0.182 \mathrm{~mm}$ ), while F1 broiler control has femur length $(8.65 \pm 0.262 \mathrm{~mm})$ and tibia (11.77 \pm $0.276 \mathrm{~mm}$ ). GK-Bro having pelung as parental from both sides, thus this crossing gives rise to the morphometric ratio of the foot which is closer to the pelung than the broiler.

Its feet size is much shorter than $F_{1}$ broilers because in general filial results of in-breeding crosses (F2, F3, etc.) have smaller sizes along with the level of the crossing. Such crosses can give rise to dwarf chickens. This can occur because the expression of genes that arise with inbreeding marriages previously leaves recessive genes that are expressed in subsequent offspring (Visscher et al., 2008; Kristensen et al., 2011; Cassell, 2007; Charlesworth \& Willis, 2009). The hen used is $F_{2}$ golden camphor and $F_{2}$ broiler which is the result of marriage inbreeding from the first filial.

\section{CONCLUSION}

The ratio of tibia and femur in GK-Bro chickens tends to inherit pelung characters as parental, but the average length is shorter than $F_{1}$ broiler and pelung, GK-Bro chicken has low productivity to consumption purpose. The qualitative character of GK-Bro inherits its parental character because of the activity of polygene. Broiler crossing with Golden Kamper succeeded in reducing the expression of dominant white genes in filial chicken feathers, resulting in four classes of feather phenotypes consisting of brown-black, white black,brown-white and white. Shank color classified into three phenotypic class which is white, yellow and blackish, while the phenotype forms a single cockscomb for all filial chicken populations.

\section{REFERENCES}

Applegate TJ, and Lilburn MS. 2002. Growth of the femur and tibia of a commercial broiler line. Poultry Science. vol 81(9): 1289-1294. doi: https://doi.org/10.1093/ps/81.9.1289.

Ben-Zaken S, Richard V, Tenenbaum G. 2019. Genetics and the psychology of motor performance (Routledge Research in Sport 
and Exercise Science). $1^{\text {st }}$ ed, Kindle Edition. Abingdon: Routledge. pp 210.

Cahill JP, and Provance MC. 2002. Genetics of Qualitative Traits in Domesticated Chia (Salvia hispanica L.). Journal of Heredity. vol 93(1): 52-55. doi: https://doi.org/10.1093/jhered/93.1.52.

Cassell B. 2007. Mechanisms of inbreeding depression and heterosis for profitable dairying. Proceeding of 4th Biennial W.E. Peterson Symposium, Crossbreeding of Dairy Cattle: The Science and the Impact. April 2, 2007. Minnesota: St. Paul Campus. pp. 1-6.

Chang VS, Lejeune J, Cheng KM. 2010. The pattern of inheritance of melanin-based plumage color variants in the Gyrfalcon (Falco rusticolus). Journal of Raptor Research. vol 44(3): 224-232. doi: https://doi.org/10.3356/JRR-09-61.1.

Charlesworth D, and Willis J. 2009. The genetics of inbreeding depression. Nature Review Genetics. vol 10: 783-796. https://doi.org/10.1038/nrg2664.

Dharmawan R, Prayogi HS, Nurgiartiningsih VMA. 2016. Penampilan produksi ayam pedaging yang dipelihara pada lantai atas dan lantai bawah. Jurnal Ilmu-Ilmu Peternakan. vol 26(3): 27-37. doi: http://dx.doi.org/10.21776/ub.jiip.2016.02 6.03.05.

Habibah I. 2018. Karakter fenotip, koefisien inbreeding, dan polimorfisme gen ctyr intron 4 pada ayam (Gallus gallus gallus Linnaeus, 1758) hibrida Golden Kamper. [Skripsi]. Yogyakarta: Fakultas Biologi, Universitas Gadjah Mada. pp. 5-6.

Henuk YL, and Bakti D. 2016. Husbandry systems of keeping native chickens in tropical areas of Indonesia. Proceeding of $1^{\text {st }}$ International Conference on Tropical Animal Science and Production. July 2629. Thailand: Suranaree University of Technology. ISBN 978-974-533-710-7. pp. 147-150.

Hidayat N, Sumantri C, Afnan R, Arifiantini RI. 2016. Penentuan konsentrasi sodium dodecyl sulfate dalam pengencer ringer laktat-kuning telur untuk preservasi semen ayam pelung. Jurnal Kedokteran Hewan. vol 10(2): 170-174. doi: https://doi.org/10.21157/j.ked.hewan.v10i 2.5091 .

Hidayat C, and Asmarasari SA. 2015. Native chicken production in Indonesia: a review. Jurnal Peternakan Indonesia. vol 17(1): 111. doi: https://doi.org/10.25077/jpi.17.1.111.2015.

Kristensen TN, Knudsen MR, Loeschcke V. 2011. Slow inbred lines of Drosophila melanogaster express as much inbreeding depression as fast inbred lines under seminatural conditions. Genetica. vol 139(4): 441-451. doi: https://doi.org/10.1007/s10709-011-95633.

Lesmana I. 2016. Asosiasi polimorfisme promoter gen Fshr dengan perkembangan folikel ovarium ayam hibrida [Gallus gallus gallus (Linnaeus, 1758)] hasil persilangan betina ras petelur dengan jantan pelung. [Skipsi]. Yogyakarta: Fakultas Biologi, Universitas Gadjah Mada. pp. 6-9.

Li S, Wang C, Yu W, Zhao S, Gong Y. 2012. Identification of Genes Related to White and Black Plumage Formation by RNASeq from White and Black Feather Bulbs in Ducks. PLoS One. vol 7(5): e36592. doi: https://dx.doi.org/10.1371\%2Fjournal.pon e.0036592.

Lobo I. 2008. Pleiotropy: One gene can affect multiple traits. Nature Education. vol 1(1):10.

Mahardhika IWS, and Daryono BS. 2019. Phenotypic performance of kambro crossbreeds of female broiler cobb 500 and male pelung blirik hitam. Buletin Veteriner Udayana. vol 11(2): 188-202. doi: https://doi.org/10.24843/bulvet.2019.v11.i 02.p12.

Maw AA, Shimogiri T, Riztyan, Kawabe K, Kawamoto Y, Okamoto S. 2012. Genetic diversity of myanmar and indonesia native chickens together with two jungle fowl species by using 102 indels polymorphisms. Asian-Australasian Journal of Animal Sciences. vol 25(7): 927-934.

doi: 
http://dx.doi.org/10.5713/ajas.2011.11511

McGraw KJ, Safran RJ, Wakamatsu K. 2005. How feather colour reflects its melanin content. Functional Ecology. vol 19(5): 816-821.

doi: https://doi.org/10.1111/j.13652435.2005.01032.x.

Minvielle F, Gourichon D, Monvoisin JL. 2002. Testing homology of loci for two plumage colors, "lavender" and "recessive white," with chicken and japanese quail hybrids. Journal of Heredity. vol 93(1): 73-76. doi: https://doi.org/10.1093/jhered/93.1.73.

Mir NA, Rafiq A, Kumar F, Singh V, Shukla V. 2017. Determinants of broiler chicken meat quality and factors affecting them: a review. Journal of Food Science and Technology. vol 54(10): 2997-3009. doi: https://dx.doi.org/10.1007\%2Fs13197017-2789-z.

Moiseyevaa IG, Romanov MN, Nikiforova AA, Sevastyanovac AA, Semyenova SK. 2003. Evolutionary relationships of Red Jungle Fowl and chicken breeds. Genetic Selection Evolution. vol 35(4): 403-423. doi: https://doi.org/10.1051/gse:2003031.

Nataamijaya AG. 2000. The native chicken of Indonesia. Buletin Plasma Nutfah. vol 6(1): 1-6.

Nataamijaya AG. 2005. Karakteristik penampilan pola warna, bulu, kulit, sisik kaki dan paruh ayam pelung di Garut dan ayam sentul di Ciamis. Buletin Plasma Nufah. vol 11 (1): 1.doi: http://dx.doi.org/10.21082/blpn.v11n1.200 5.p1-5.

Puspita UE, Utomo RT, Perdamaian ABI, Lesmana I, Arijuddin H, Erwanto Y,
Daryono BS, Saragih HTSG. 2017. Effect of varying levels of protein and energy in pre-stater feeds on pectoralis muscle development of Kampung Super Chicks (Gallus gallus gallus). Asian Journal of Animal and Veterinary Advances. vol 12(1): 31-37. doi: http://dx.doi.org/10.3923/ajava.2017.31.3 7.

Salaam ZK, Akinyemi MO, Osamede OH. 2016. Effect of strain and age on bone integrity of commercial broiler chickens. Biotechnology in Animal Husbandry. vol 32 (2): 195-203. doi: https://doi.org/10.2298/BAH1602195S.

Setianto J, Zain B, Sutriyono, Prakoso H. 2017. Domestication of red jungle fowl: A case study of the red jungle fowl chicks procurement by the communities in Central Bengkulu, Indonesia. Biodiversitas. vol 18(1): 183-189. doi: http://dx.doi.org/10.13057/biodiv/d18012 5.

Ulfah M, Perwitasari D, Jakaria, Muladno, Farajallah A. 2015. Breed determination for Indonesian local chickens based on matrilineal evolution analysis. International Journal of Poultry Science. vol 14(11): 615-621.

Visscher P, Hill W, Wray N. 2008. Heritability in the genomics era-concepts and misconceptions. Nature Review Genetics. vol 9: 255-266. doi: https://doi.org/10.1038/nrg2322.

Wiebe KL, and Bortolotti GR. 2001. Variation in colour within a population of northern flickers: a new perspective on an old hybrid zone. Canadian Journal of Zoology. vol 79(6): 1046-1052. doi: https://doi.org/10.1139/z01-065. 